\title{
Article
}

\section{Open-Innovation Practices: Diversity in Portuguese SMEs}

\author{
Fernando Almeida (D)
}

check for updates

Citation: Almeida, F. Open-Innovation Practices: Diversity in Portuguese SMEs. J. Open Innov. Technol. Mark. Complex. 2021, 7, 169. https: / / doi.org/10.3390/ joitmc7030169

Received: 31 May 2021

Accepted: 1 July 2021

Published: 5 July 2021

Publisher's Note: MDPI stays neutral with regard to jurisdictional claims in published maps and institutional affiliations.

Copyright: (C) 2021 by the author. Licensee MDPI, Basel, Switzerland. This article is an open access article distributed under the terms and conditions of the Creative Commons Attribution (CC BY) license (https:// creativecommons.org/licenses/by/ $4.0 /)$.
Institute for Systems and Computer Engineering, Technology and Science (INESC TEC), Polytechnic Institute of Gaya (ISPGAYA), University of Porto, 4000-008 Porto, Portugal; almd@fe.up.pt; Tel.: +351-22209-4000

\begin{abstract}
This study aimed to explore the diversity of open-innovation practices that are adopted in Portuguese SMEs considering the outside-in, inside-out, and coupled paradigms. A quantitative study was carried out considering a sample of 187 Portuguese SMEs. The findings revealed that these organizations favored the adoption of the outside-in paradigm. The inside-out model was the least relevant, especially for smaller companies (i.e., small and micro-companies). The most adopted outside-in practices were the integration of external knowledge from suppliers and clients; in the inside-out model, licensing processes were more important; while in the coupled model, joint ventures and network consortiums stood out. The increase in the innovation capacity of these organizations was highlighted as the most relevant benefit, while the lack of resources and difficulties in integrating knowledge emerged as challenges. This study is especially relevant for the establishment of public-support policies that promote the involvement of Portuguese SMEs in open-innovation processes.
\end{abstract}

Keywords: open innovation; outside-in model; inside-out model; coupled model; openness; external knowledge

\section{Introduction}

In a dynamic economy, influenced by profound social changes and technological evolutions, innovation assumes a decisive relevance in economic growth, the creation of competitive advantages, and the sustainability of organizations [1-4]. Innovation can be understood as a process of continuous learning and research that results in exploring new ideas successfully in the market. Subsequently, these ideas can be incorporated into new or improved products/services, processes, or organizational methods that, in new types of associations and markets, improve performance [5].

In the traditional innovation model, based on the closed-innovation paradigm, companies rely primarily on internal knowledge and skills for the development of new innovations [6]. In this context, organizations invest in highly qualified human capital and in internal research-and-development processes to generate competitive advantages [6]. According to [7], this model requires a high control of organizational processes to protect internal intellectual property and avoid or strongly restrict the interactions and exchanges of resources and internal knowledge with agents outside the organization.

However, the dynamics and evolution of the economy and markets have led to greater competitiveness among companies and the emergence of a global market [8,9]. This new paradigm demands new ways of organizing internal processes, and has led to the emergence of a more open and collaborative innovation model. We are witnessing the emergence of new communication technologies, the increased mobility of highly qualified employees, and the need to reduce R\&D costs. Consequently, it is crucial to optimize internal processes and integrate external processes to guarantee the competitiveness of organizations [10].

It is in this context that the concept of open innovation proposed by Chesbrough in 2003 [11] arises, in which collaboration between companies, individuals, and public agencies is encouraged in the creation of new products and services. This concept has 
implicit changes in organizations, no longer considering innovation as an individual act, but assuming that it depends on the exchange of knowledge flows between various external sources to enhance the value of innovation. The challenge for organizations is then to find the balance between coordinating and integrating knowledge and internal and external competencies [12].

For small and medium-sized companies (SMEs), open innovation presents itself as a way for these companies to overcome certain dimensions resulting from their size, and thus be able to adapt and thrive in an increasingly competitive and turbulent environment $[13,14]$. Data from Eurostat $[15]$ indicate that SMEs dominate the business fabric in Portugal, representing $99.3 \%$ of companies and the second-highest country in the European Union in terms of weight of SMEs, only behind Italy. Despite the growing interest in the business application of the concept of open innovation, most studies in the area still tend to focus primarily on large companies. Given the particularities that distinguish SMEs from other companies, it is relevant to explore the diversity of practices of implementation of open innovation in the context of a country like Portugal, the role of SMEs in which is crucial for its growth and economic and social sustainability. In this context, this study addresses the research gap in the implementation of open-innovation practices, benefits, and challenges in the specific context of SMEs, and allows for a better understanding of this phenomenon and the establishment of public policies and recommendations to stimulate open-innovation activities in these companies. The rest of this manuscript is organized as follows: In an initial phase, a theoretical contextualization of the various models of open innovation implementation is performed. The main benefits and challenges of implementing open innovation are also addressed. Next, the methods adopted to carry out the study are presented. This is followed by the presentation and discussion of the results. Finally, conclusions are enumerated, limitations are discussed, and some suggestions for future work are provided.

\section{Background}

The approach proposed by open innovation can be seen as the antithesis of the traditional closed-innovation model of vertical integration, in which products/services are totally developed by a single company. In the closed-innovation paradigm, the projects begin based on in-house knowledge and technologies, followed by a development phase in which some projects are progressively eliminated for not revealing a high potential for the company, with a smaller number of projects that will reach the market as new products or services resulting from this process [16]. It is considered a closed process because, since its conception, the process control is performed only by the company, and the projects have only one way to enter and leave the process. Moreover, the company's limits are perfectly delimited.

In contrast, in the new open-innovation paradigm, projects may have different sources of knowledge and technology (e.g., internal and external). Vanhaverbeke et al. [17] mentioned that these sources can enter the process in its different phases, and various exit possibilities emerge beyond the current market (e.g., licensing, spinoffs). In open-innovation processes, the organizational boundaries are not rigid, so companies can interact with their surroundings. This process includes multiple sources of internal and external technologies and multiple internal and external commercialization channels [18]. In the open-innovation paradigm, intellectual property is an important asset for the company because it constitutes an additional source of revenue and fosters the business model itself $[19,20]$.

Innovation has been considered an important strategy in obtaining competitive advantages for companies [21,22]. To innovate, firms can invest in internal research and development or stimulate external sources of knowledge. These external sources of knowledge can be exchanged through spillovers, collaborations, or direct market operations, like technology licensing [23-25]. The management of knowledge spillovers implies two directions of knowledge flow along the boundaries of the firm: an outside-in movement and an inside-out movement [26]. In addition to these motions, Enkel et al. [27] added 
a new movement called coupled, which consists of the combination of elements of the previous movements.

\subsection{Outside-In Open Innovation}

The outside-in approach consists of opening a company's innovation process to contributions from various sources from the outside. As stated by Inauen and SchenkerWicki [28], in practice, this approach involves leveraging the discoveries of third parties, which prevents the company from being exclusively dependent on its own internal $R \& D$ activities. There are several sources of external knowledge that the company can use, such as suppliers, competitors, universities, and startups, among others [29-31].

Collaborations between companies and suppliers, which are common to find in this model, aim at improving product quality, as well as reducing costs and time to market [32]. Suppliers contribute knowledge that companies need and is typically easy to integrate, since they usually belong to the same industry and share common goals. As Shcherbakov and Silkina [33] pointed out, the advantages that come from the relationship with suppliers can be strategic (e.g., access to new production techniques, reduction of financial risks) and technical (e.g., reduction of production-change orders, improvement of supply channels).

The involvement of customers at an early stage of the innovation process is another strategy that helps companies to understand consumers' needs in a timely manner. According to Sjödin et al. [34], this also contributes to obtaining external resources that make projects more agile and reduce the probability of failure of these solutions in the market. There are several ways in which companies can involve the knowledge of customers in the innovation process, such as conducting market research or joint development of products and technologies [35].

Knowledge/technological spillovers correspond to the diffusion of knowledge/ technology, making knowledge/technology no longer exclusive to an organization and able to be accessed by others, contributing to the collective knowledge. The importance of technological spillovers depends on the industrial sector, and they are greater in sectors in which there is a great intensity of R\&D and the need for highly qualified labor [36]. The spillovers may arise at backward and forward levels (vertical spillovers) and at the intra-industry level (horizontal spillovers) between local companies and multinational enterprises [37,38]. Universities are also increasingly participating in open-innovation activities, mainly through the dissemination of their research. Currently, there is a growing need for a deeper and more productive interaction between universities and industries, because in today's highly competitive environment, it is crucial for the survival and growth of a company to keep up with technological progress and to innovate continuously [39]. However, their knowledge and resources are limited, which makes it more difficult for companies to explore new technologies on their own. Therefore, universities and R\&D centers are becoming knowledge providers for industries [40-42]. However, as stated in Jonsson et al. [43], since researchers are more interested in the scientific results of research and less in its market value and have a different perception of time, this can pose an added challenge for companies. However, this does not invalidate the fact that universities are a recognized source of new knowledge in spillover theory aimed at supporting regional economic development [44]. The outside-in process also encompasses other mechanisms that help in the management of external knowledge flows such as knowledge monitoring, licensing of external technologies, or financing and participation in startups. Technology licensing concerns the purchase and use of external technologies through intellectualproperty agreements [45]. Funding and participation in startups use different mechanisms such as venture capital, incubators, and strategic alliances to build relationships with startups in their industry, and through this approach, benefit from the technologies developed by them [46].

The success of the outside-in approach implies that companies have a good absorptive capacity; i.e., the ability to recognize value in external information, assimilate it, and use it for business purposes $[47,48]$. Therefore, the cognitive constraint of firms is a factor 
that limits the adoption of this approach. Furthermore, a study conducted by Spithoven et al. [49] identified that some companies that follow the inbound strategy neglect internal technological competencies, consequently becoming too dependent on external sources of innovation.

The first research aim was to identify the outside-in practices that are applied by SMEs, and to this end, the following research question was defined:

RQ1: What are the outside-in open-innovation practices mostly adopted by Portuguese SMEs?

\subsection{Inside-Out Open Innovation}

In this paradigm, the knowledge flows from the inside to the outside of the organization. This approach requires that companies allow internally unused or underused knowledge to be disseminated to the outside. According to Bogers et al. [50], this paradigm helps companies to bring their innovations to the market, and to do so more quickly. This is a growing need, given the reduction of product life cycles [51].

Companies can adopt several strategies in the inside-out model, such as licensing intellectual-property rights, creating spinoffs based on previously developed technologies or products, or outsourcing innovation [52]. Regardless of the strategy chosen, the main goal will be to enhance internal knowledge by opening the boundaries of the company to obtain advantages by sharing ideas with the outside world.

This approach can be a strategic opportunity when companies have the capacity to develop innovations but do not have sufficient resources in the commercial area. It can also be an interesting approach for companies to take a leading role in defining the direction of R\&D activities across the industry [53]. Furthermore, this approach enables companies to avoid falling into the trap of "innovation myopia". According to Laursen and Salter [54], this is a phenomenon that occurs when companies devote excessive importance to protecting their knowledge, giving excessive importance to intellectual property and marginalizing the use of external resources and opportunities to transform innovations into commercial applications or services.

Sharing technological advances with the outside world causes companies to find it more difficult to capture the benefits that arise from them [55]. This may represent a challenge for companies because they will have to decide which internal resources to protect and which can be shared with the outside world. Silva [56] argued that for companies to obtain the benefits associated with this model of innovation, a rigorous process of protecting the profits generated by innovation through formal methods such as patents, trademark registrations, or protection of author rights is necessary. Therefore, legal protection mechanisms play a key role in this model of innovation because they contribute to share and reduce the risks associated with R\&D investments.

In line with the first research question, a second research aim was defined by focusing on inside-out practices. Therefore, the following research question was formulated:

RQ2: What are the inside-out open-innovation practices mostly adopted by Portuguese SMEs?

\subsection{Coupled Open Innovation}

Coupled open innovation requires that a combination of internal and external flows of knowledge arise in the company to collaboratively develop and/or commercialize an innovation [57]. Two or more agents can be involved in this process, generating mutual knowledge flows between their organizations. This is intended to ensure that the company gains additional knowledge while, on the other hand, it is able to bring ideas to market more effectively [58].

Coupled open innovation apparently results from a combination of the practices associated with inside-out and outside-in open innovation. However, this approach also counts on other mechanisms for its development, such as joint ventures, strategic alliances, and networks in which complementary partners can be involved [59]. 
This open-innovation model relies on a positive cooperation between both parties. By cooperating, companies can gain access to complementary knowledge from different partners, including intangible knowledge that is not easily transferable [60]. These collaborations also allow the exploitation of economies of scale in research and development, helping to reduce innovation costs [61]. However, there are also some negative aspects, because this cooperation requires an additional effort of alignment between different agents. Gallaud and Nayaradou [62] found that this situation may imply costs for the company and increase the probability of proprietary information being disclosed.

Several studies have explored collaborative processes between diverse organizations. In recent decades, the tendency for companies to locate and act in proximity has become the matrix of economic development and growth. According to Verdú and Tierno [63], clusters of productive activities belonging to a given industry in a region play a predominant role in the development of competitive advantages for the region and companies. Leenders and Dolfsma [64] examined the role of social-network analysis in the development of new products involving four levels (i.e., networks within a firm, networks that cross firm boundaries, networks between firms, and networks that reside outside a firm). Finally, Montoro-Sánchez et al. [65] discussed the role of collaboration among startups in promoting innovation and growth in these organizations. In line with the previous two research questions, a new research question was defined that explores practices in the context of coupled open innovation:

RQ3: What are the practices of coupled open innovation mostly adopted by Portuguese SMEs?

\subsection{The Relevance of Open Innovation in SMEs}

Studies by Hossain [66] show that SMEs are usually less bureaucratic and more risk-taking. Their flexibility, agility, and focus/niche strategy for a particular product or service allows them to innovate faster [67]. However, their small size means that these organizations have limited financial resources and use few structured and solidified innovation processes. Taken together, this constitutes a constraint on their ability to innovate and become competitive [68].

Open innovation can be seen by SMEs as a possible way to adapt and thrive in an increasingly competitive and turbulent environment, and to overcome their limitations [69,70]. By applying open innovation, SMEs will be able to compensate for their lack of internal resources and competencies by using external resources to develop new technologies and take advantage of market opportunities. Henttonen and Lehtimäki [71] highlighted the role that technology licensing can play for SMEs, since it can allow them to accelerate the internal innovation process and fill technology gaps existing internally. This approach can benefit the innovative performance of SMEs by allowing the incorporation of tried and tested technologies that will contribute to the development of new and complex products/services. Risk sharing is another benefit found in the literature that becomes particularly relevant in high-tech investments with increased risk [72]. Investment diversification is another relevant advantage that allows SMEs to diversify their line of products and services [73]. Finally, in Paulo et al. [74], it also was mentioned that open innovation allows organizations to increase their competitiveness and the effectiveness of their products/services acceptance in the market.

Despite the unequivocal benefits associated with the practices of innovation in SMEs, studies have also shown that these types of companies have greater difficulty in developing mechanisms capable of effectively implementing open innovation due to their size [75,76]. In these studies, it was emphasized that the greater flexibility and adaptability of these organizations did not compensate for the lack of resources and skills to develop a culture of permanent innovation. Faria et al. [77] also confirmed this view by highlighting the difficulties of SMEs in absorbing and exploring scientific discoveries, which consequently made it difficult for them to integrate and monitor external knowledge in the internal innovation process. The loss of control was another challenge highlighted by Rauter 
et al. [78], while Aquilani et al. [79] underlined the cultural barriers that emerged from the collaborative participation of a large number of diversified players.

Exploring both benefits and challenges in the context of applying open innovation in Portuguese SMEs is a relevant work, and to this end, the following two research questions were proposed:

RQ4: What are the benefits of implementing open innovation for Portuguese SMEs?

RQ5: What are the challenges of implementing open innovation for Portuguese SMEs?

\section{Materials and Methods}

In this study, a quantitative methodology was used through a cross-sectional survey involving SMEs from several activity sectors. According to Bergin [80], this approach would allow us to gather data about the motivations of specific groups, and to understand and interpret certain behaviors, opinions, and expectations of a specific group of individuals.

Portuguese SMEs were identified from the Institute to Support Small and MediumSized Companies. We considered the companies listed in the PME Líder 2020 edition, in which a total of 9955 SMEs are included. After that, we collected a sample of 612 SMEs while respecting the geographical distribution of these companies to reduce the risk of bias. The contact data of these companies were collected from the institutional information for each company. In the sample, the proportion of SMEs was respected, considering their geographical distribution, size, and sector. A pilot questionnaire was distributed to 12 partner companies of our research center at the end of January 2021 to collect suggestions for improvement that would allow increasing the focus on the main practices, benefits, and challenges of open innovation. The scale was also corrected to adopt a Likert scale of five levels for the dimensions of benefits and challenges. After that, the questionnaire was distributed by email between February and April 2021. There were no financial or material incentives to respond to the survey. A total of 193 companies answered the survey, representing a response rate of $31.54 \%$. From the total of responses obtained, 6 were withdrawn, representing companies that did not meet the SME criteria according to the European Commission's benchmarks [81]: (i) a medium-sized company has less than 250 workers or a turnover less than EUR 50 million; (ii) a small-sized company has less than 50 workers or a turnover less than EUR 10 million; and (iii) a micro company has less than 10 workers and a turnover less than EUR 2 million. In the end, the sample consisted of 187 Portuguese SMEs.

The questionnaire consisted of three sections, as shown in Table 1. The first section included three control variables that aimed to characterize the essential characteristics of a company such as the business sector, number of years in business, and number of employees. The second section explored the practices of outside-in, inside-out, and coupled open innovation adopted by organizations. For this purpose, the relevance of these practices and the mechanisms of knowledge transfer used for this purpose were explored. Finally, the third section examined the benefits and challenges experienced by Portuguese SMEs in implementing open innovation. The full structure of the questionnaire is available in the Appendix A.

Table 2 characterizes the sample of responses received in this study. The responses received were grouped according to the three business sectors with the greatest representation. In total, the EACC has 17 business sectors, hence the "others" class represents 14 sectors such as construction, real estate, financial services, and education, among others. Most SMEs had been in the market for more than 10 years and were mostly small companies. 
Table 1. Overview of survey structure.

\begin{tabular}{|c|c|c|}
\hline Section & Question & Answer Alternatives \\
\hline \multirow{3}{*}{ Control data } & Business sector & $\begin{array}{l}\text { Economic Activities Classification Code } \\
\text { (EACC) in Portugal }\end{array}$ \\
\hline & Number of years of activity & Less than 3 , between 3 and 10 , more than 10 \\
\hline & Number of employees & Less than 250 , less than 50 , less than 10 \\
\hline \multirow{6}{*}{ Open-innovation practices } & $\begin{array}{l}\text { What is the relevance of outside-in open } \\
\text { innovation for your company? }\end{array}$ & $\begin{array}{c}\text { Likert scale (very low, low, moderate, high, } \\
\text { very high) }\end{array}$ \\
\hline & $\begin{array}{l}\text { What practices are adopted in the } \\
\text { outside-in process? }\end{array}$ & $\begin{array}{l}\text { Suppliers, customers, competitors, } \\
\text { universities, and R\&D centers, }\end{array}$ \\
\hline & $\begin{array}{l}\text { What is the relevance of inside-out open } \\
\text { innovation for your company? }\end{array}$ & $\begin{array}{c}\text { Likert scale (very low, low, moderate, high, } \\
\text { very high) }\end{array}$ \\
\hline & $\begin{array}{l}\text { What practices are adopted in the } \\
\text { inside-out process? }\end{array}$ & $\begin{array}{c}\text { Licensing, creation of a spinoff, outsourcing } \\
\text { of innovation }\end{array}$ \\
\hline & $\begin{array}{l}\text { What is the relevance of coupled open } \\
\text { innovation for your company? }\end{array}$ & $\begin{array}{l}\text { Likert scale (very low, low, moderate, high, } \\
\text { very high) }\end{array}$ \\
\hline & $\begin{array}{l}\text { What practices are adopted in the } \\
\text { coupled process? }\end{array}$ & $\begin{array}{l}\text { Joint ventures, strategic alliances, } \\
\text { network consortiums }\end{array}$ \\
\hline \multirow[t]{2}{*}{ Benefits and challenges } & $\begin{array}{l}\text { What are the benefits of open innovation } \\
\text { for your company? }\end{array}$ & $\begin{array}{l}\text { Development of innovative capacity, cost } \\
\text { reduction, diversification, reduced time to } \\
\text { market, risk-sharing, increased acceptance } \\
\text { of innovations }\end{array}$ \\
\hline & $\begin{array}{l}\text { What are the challenges of open } \\
\text { innovation for your company? }\end{array}$ & $\begin{array}{l}\text { Lack of resources, lack of competencies, } \\
\text { difficulties in integrating knowledge, loss of } \\
\text { control, cultural challenges }\end{array}$ \\
\hline
\end{tabular}

Table 2. Characterization of the sample.

\begin{tabular}{ccc}
\hline Question & Absolute Frequency & Relative Frequency \\
\hline Business sector & 72 & \\
Trade and retail & 41 & 0.3850 \\
Manufacturing & 30 & 0.2193 \\
Accommodation and catering & 44 & 0.1604 \\
Others & & 0.2353 \\
Number of years of activity & 21 & \\
Less than 3 & 52 & 0.1123 \\
Between 3 and 10 & 114 & 0.2781 \\
More than 10 & & 0.6096 \\
Number of employees & 29 & 0.1551 \\
Less than 250 & 142 & 0.7594 \\
Less than 50 & 16 & 0.0856 \\
Less than 10 & &
\end{tabular}

Finally, the internal consistency of the questionnaire was assessed. Hoekstra et al. [82] stated that internal consistency measures the extent to which the items that compose it measure the same concept or construct. To measure internal consistency, the Cronbach's coefficient alpha (CCA) was used. The results in Table 3 indicate a sufficiently acceptable level of internal consistency as recommended by Taber [83], who stated that the minimum acceptable value is 0.7 . 
Table 3. Internal consistency of the questionnaire.

\begin{tabular}{cccc}
\hline Construct & CCA & $\begin{array}{c}\text { CCA Based on } \\
\text { Standardized Items }\end{array}$ & No. of Items \\
\hline Control data & 0.7682 & 0.7988 & 3 \\
Open-innovation practices & 0.8341 & 0.8457 & 6 \\
Benefits and challenges & 0.7150 & 0.7395 & 2 \\
\hline
\end{tabular}

\section{Results}

Table 4 explores the relevance of open-innovation practices for Portuguese SMEs. The collected data showed a higher relevance given to the outside-in model. On the contrary, the inside-out model was the practice identified with the least relevance. The coupled model was more relevant than the inside-out model, which revealed that organizations felt more committed to participating in collaborative modes in which inside-out practices were complemented outside-in. In isolation, the inside-out model was not very appealing to Portuguese SMEs, although there was a greater dispersion of answers in this component.

Table 4. Relevance of open-innovation practices.

\begin{tabular}{cccc}
\hline Model & Mean & Median & Std. Dev. \\
\hline Outside-in & 3.977 & 4 & 0.781 \\
Inside-out & 2.855 & 3 & 1.258 \\
Coupled & 3.212 & 3 & 1.091 \\
\hline
\end{tabular}

Table 5 presents the correlation between the various innovation practices considering the three perspectives (i.e., outside-in, inside-out, and coupled). The results indicated several correlations among the practices, including: (i) the existence of a significant positive correlation among the various innovation practices; (ii) the adoption of outside-in practices was not correlated with inside-out practices; and (iii) outside-in and coupled practices showed significant positive correlation, indicating that SMEs simultaneously adopted more than one practice in each dimension.

Table 5. Correlations between open-innovation practices.

\begin{tabular}{|c|c|c|c|c|c|c|c|c|c|c|c|c|c|}
\hline Variable & Mean & $\begin{array}{l}\text { Std. } \\
\text { Dev. }\end{array}$ & 1 & 2 & 3 & 4 & 5 & 6 & 7 & 8 & 9 & 10 & 11 \\
\hline 1 & 0.4388 & 0.078 & & & & & & & & & & & \\
\hline 2 & 0.2347 & 0.056 & $0.327^{* * *}$ & & & & & & & & & & \\
\hline 3 & 0.1224 & 0.047 & $0.189^{* * *}$ & $0.257^{* * *}$ & & & & & & & & & \\
\hline 4 & 0.1122 & 0.044 & $0.246^{* * *}$ & $0.159^{* * *}$ & $0.098 * *$ & & & & & & & & \\
\hline 5 & 0.0918 & 0.043 & $0.237^{* * *}$ & $0.163^{* * *}$ & $0.167^{* * *}$ & $0.383 * * *$ & & & & & & & \\
\hline 6 & 0.7451 & 0.118 & -0.026 * & -0.037 * & -0.013 & $0.078^{* *}$ & $0.107^{* * *}$ & & & & & & \\
\hline 7 & 0.0784 & 0.076 & -0.011 & -0.015 & -0.005 & $0.101^{* * *}$ & $0.129^{* * *}$ & 0.104 & & & & & \\
\hline 8 & 0.1765 & 0.091 & -0.023 * & -0.021 * & $-0.017^{*}$ & 0.039 * & 0.044 * & $0.079 * *$ & $0.052 *$ & & & & \\
\hline 9 & 0.6471 & 0.110 & $0.045 *$ & $0.053 *$ & $0.049 *$ & $0.023 *$ & $0.034 *$ & $0.056 *$ & $0.036 *$ & $0.047 *$ & & & \\
\hline 10 & 0.1373 & 0.095 & $0.041 *$ & $0.046^{*}$ & 0.052 * & 0.018 & 0.028 & 0.031 & 0.028 & 0.032 & 0.038 & & \\
\hline 11 & 0.5098 & 0.106 & 0.018 & 0.029 & 0.021 & 0.011 & 0.021 & 0.033 & 0.024 & 0.028 & $0.059 *$ & 0.068 * & \\
\hline
\end{tabular}

Note: ${ }^{* * *} p<0.01,{ }^{* *} p<0.05,{ }^{*} p<0.1$.

Figure 1 presents an infographic of the open-innovation practices: window A compares the relative relevance of open-innovation practices; window B shows the outsidein practices; window $C$ presents the inside-out practices; and window $\mathrm{D}$ shows the coupled practices. 


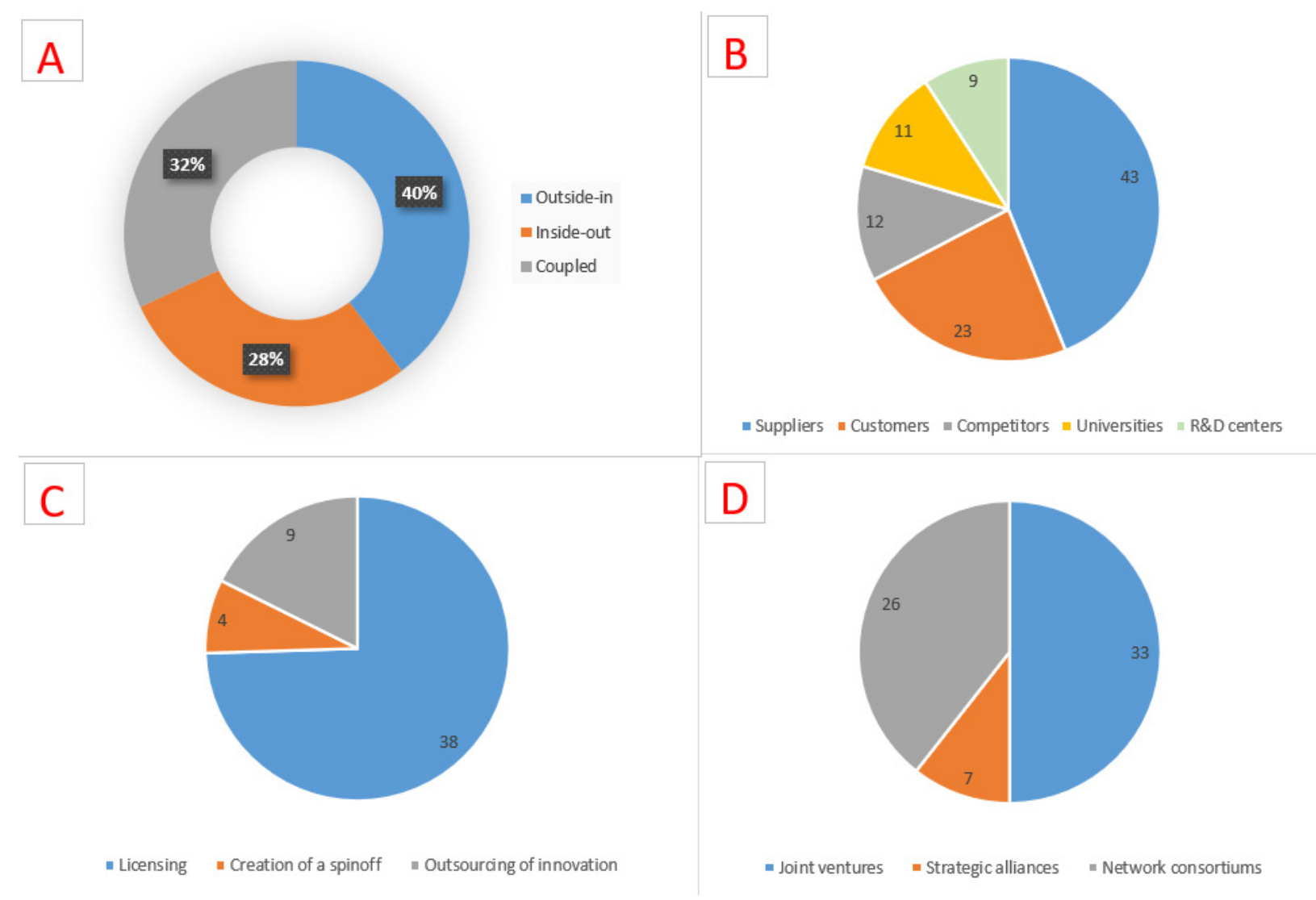

Figure 1. Infographic of open-innovation practices.

For RQ1, the outside-in practices implemented by Portuguese SMEs were explored. A total of 98 companies acknowledged implementing outside-in innovation practices. The access to knowledge by suppliers stood out as the most adopted practice, with 43 answers (43.88\%), followed by customers, with 23 answers $(23.47 \%)$. Together, these two practices represented more than $65 \%$ of the outside-in initiatives.

RQ2 examined inside-out practices. These types of practices were implemented in only 51 of the surveyed SMEs. The most adopted practice by organizations was licensing, which represented almost $75 \%$ of the responses. On the opposite side, the creation of a spinoff was still a practice with residual representation (lower than $8 \%$ ).

Finally, RQ3 explored the coupled open-innovation practices This paradigm was adopted by 66 of the surveyed SMEs. Joint ventures were the most adopted practice, with 33 answers (64.71\%), followed by involvement in network consortiums, with 26 answers $(50.98 \%)$. On the opposite side, strategic alliances were less than $15 \%$.

The benefits of open innovation for Portuguese SMEs were also explored as predicted in RQ4. The results in Figure 2 indicate that the development of innovative capabilities was the main benefit identified by these organizations. This was the main factor, with a weight greater than $70 \%$. The other benefits were less important, especially those related to cost reduction and increased market acceptance of innovations. These two benefits did not exceed $10 \%$ of the answers. 


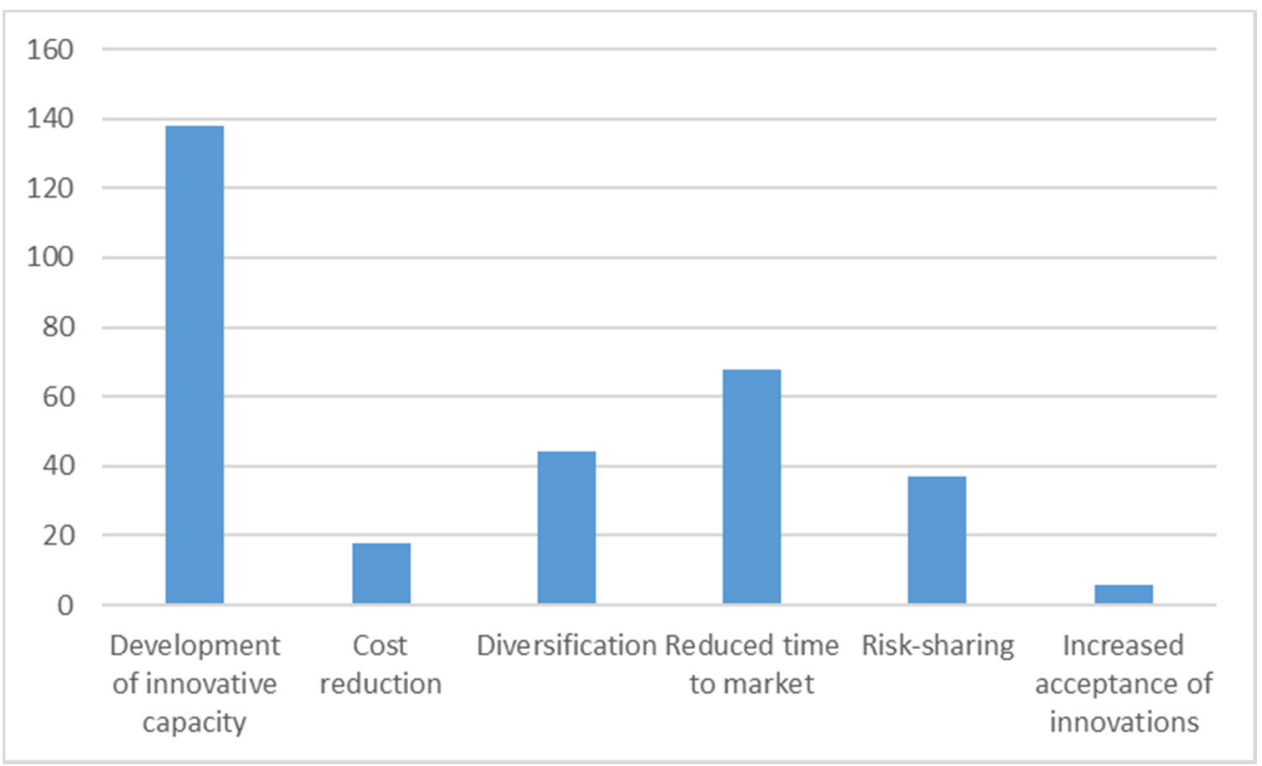

Figure 2. Benefits of open innovation for Portuguese SMEs.

Figure 3 shows the challenges posed by open-innovation practices in Portuguese SMEs as established in RQ5. A lack of resources was identified in a total of 149 responses $(79.68 \%)$, and the difficulties in integrating knowledge from open-innovation processes in 122 responses $(65.24 \%)$. On the opposite side, the loss of control and cultural barriers had a much smaller weight, and were less than $20 \%$.

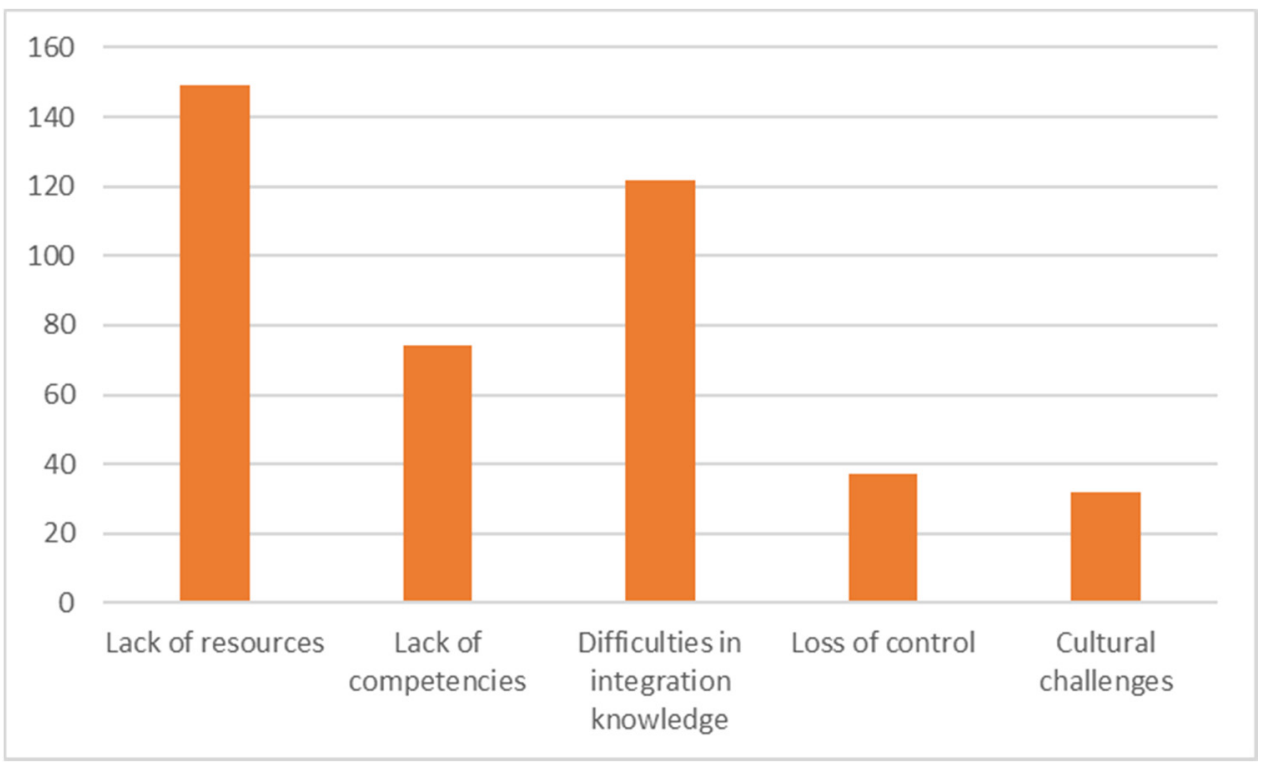

Figure 3. Challenges of open innovation for Portuguese SMEs.

An analysis of variance (ANOVA) was also conducted to explore the role of control variables in interpreting the practices, benefits, and challenges of open innovation. According to Vik [84], ANOVA is a procedure that can be used to compare the distribution of three or more independent sample groups. In this study, it was applied to explore the impact of the business sector, number of years of activity, and number of employees of Portuguese SMEs. A significance level of $5 \%(\alpha=0.05)$ was adopted.

Table 6 presents the result of applying ANOVA for the business sector. The three most representative activity sectors of the sample (i.e., trade and retail, manufacturing, and 
accommodation and catering) were considered. The findings showed that the business sector was not a relevant dimension in understanding the behavior of Portuguese SMEs.

Table 6. ANOVA analysis for the business sector.

\begin{tabular}{cccc}
\hline Variable & Trade and Retail & Manufacturing & Accommodation and Catering \\
\hline Practices & & & 0.458 \\
Outside-in & 0.672 & 0.429 & 0.290 \\
Inside-out & 0.341 & 0.392 & 0.232 \\
Coupled & 0.566 & 0.353 \\
Benefits & & 0.269 & 0.310 \\
Cost reduction & 0.346 & 0.235 & 0.078 \\
Diversification & 0.127 & 0.677 & 0.381 \\
Reduced time to market & 0.458 & 0.452 & 0.231 \\
Risk-sharing & 0.268 & 0.327 & 0.420 \\
Chelop & 0.560 & 0.296 & 0.122 \\
Lack of resources & 0.156 & 0.177 & 0.114 \\
Lack of competencies & & 0.292 & 0.178 \\
Diff. in integration knowledge & 0.286 & 0.427 & 0.340 \\
Loss of control & 0.221 & 0.142 & 0.138 \\
Cultural challenges & 0.198 & 0.521 & 0.581 \\
\hline
\end{tabular}

Table 7 presents the result of applying ANOVA for the number of years of activity. Some significant differences emerged in the identification of the benefits associated with the development of the innovative capacity of organizations. SMEs with less than three years of activity favored the adoption of open innovation for the development of their innovative capacity. On the challenges, SMEs with more than 10 years of activity presented greater difficulties in integrating knowledge arising from open innovation; on the contrary, younger companies (i.e., with less than 3 years of activity) showed greater ease in incorporating this external knowledge.

Table 7. ANOVA analysis for the number of years of activity.

\begin{tabular}{cccc}
\hline Variable & Less than $\mathbf{3}$ & Between $\mathbf{3}$ and $\mathbf{1 0}$ & More than 10 \\
\hline Practices & & & \\
Outside-in & 0.220 & 0.162 & 0.234 \\
Inside-out & 0.322 & 0.193 & 0.264 \\
Coupled & 0.167 & 0.292 & \\
Benefits & & & $<1 \times 10^{-3}$ \\
Develop of innovative capacity & $<1 \times 10^{-3}$ & $<1 \times 10^{-3}$ & 0.179 \\
Cost reduction & 0.257 & 0.195 & 0.310 \\
Diversification & 0.388 & 0.372 & 0.239 \\
Reduced time to market & 0.128 & 0.250 & 0.225 \\
Risk-sharing & 0.167 & 0.122 & 0.171 \\
Increased accept of innovation & 0.199 & 0.125 & 0.111 \\
Challenges & & & 0.108 \\
Lack of resources & 0.190 & 0.079 & 0.003 \\
Lack of competencies & 0.121 & 0.152 & 0.231 \\
Diff. in integration knowledge & 0.012 & 0.097 & 0.188 \\
Loss of control & 0.256 & 0.192 &
\end{tabular}

Table 8 presents the results of applying ANOVA to the number of employees. Significant differences emerged in inside-out innovation practices, which tended to be implemented more in larger organizations (i.e., medium-sized companies). In the benefits dimension, significant differences were found in the development of innovative capacity, 
reduced time to market, and risk-sharing. Smaller SMEs emphasized these benefits the most. On the other hand, these companies showed greater difficulties due to the existence of few resources and skills dedicated to open innovation. However, the greatest difficulties in integrating the knowledge generated by open innovation were found in medium-sized companies.

Table 8. ANOVA analysis for the number of employees.

\begin{tabular}{cccc}
\hline Variable & Less Than 250 & Less Than 50 & Less Than 10 \\
\hline Practices & & & \\
Outside-in & 0.211 & 0.143 & 0.245 \\
Inside-out & 0.005 & 0.107 & 0.063 \\
Coupled & 0.120 & 0.098 & 0.171 \\
Benefits & & & \\
Cost reduction & 0.155 & $<1 \times 10^{-3}$ & $<1 \times 10^{-3}$ \\
Develop innovative capacity & 0.230 & 0.113 & 0.178 \\
Diversification & $<1 \times 10^{-3}$ & $<1 \times 10^{-3}$ & $<1 \times 10^{-3}$ \\
Reduced time to market & $<1 \times 10^{-3}$ & $<1 \times 10^{-3}$ & $<1 \times 10^{-3}$ \\
Risk-sharing & 0.292 & 0.206 & 0.230 \\
Increased accept of innovation & & & $<1 \times 10^{-3}$ \\
Challenges & $<1 \times 10^{-3}$ & $<1 \times 10^{-3}$ & $<1 \times 10^{-3}$ \\
Lack of resources & $<1 \times 10^{-3}$ & $<1 \times 10^{-3}$ & 0.115 \\
Lack of competencies & $<1 \times 10^{-3}$ & 0.091 & 0.383 \\
Diff. in integration knowledge & 0.341 & 0.290 & 0.232 \\
Loss of control & 0.196 & 0.156 &
\end{tabular}

\section{Discussion}

The study revealed that outside-in practices tended to be the most privileged in the context of Portuguese SMEs. In this model, innovation competencies were sought through integration with external knowledge (e.g., clients, suppliers, universities). Most Portuguese SMEs are looking for innovative solutions for opportunities in the company, in particular by bringing technologies and knowledge from outside into the company. This is one of the first steps in implementing open innovation, as recognized in Arvanitis et al. [85], since it is the one that requires the least restructuring of the organizational model. However, more demanding challenges are involved in reshaping business models until the ecosystem concept is achieved, and thus becoming a multi-platform enabler. The sharing of internal knowledge with the outside is a practice that assumes less relevance. Gómez et al. [86] argued that internally generated intellectual property that is not being used within the company can be internalized or commercialized. However, the low level of maturity of the innovation processes in Portuguese SMEs is an inhibiting factor for its implementation. This view is supported in COTEC Portugal's 2020 report, which indicated an overall low level of digital maturity of organizations and their management processes [87]. Therefore, coupled open innovation assumes an even higher weight than the practices related to inside-out. This happens because the most advanced SMEs combine both strategies in their open-innovation processes. This coupled approach is more challenging, but allows the adopting SMEs to fulfill specific knowledge needs that arise through interaction between the parties, which also results in intensive knowledge exchange and mutual learning [88]. On the contrary, the inside-out approach was still the practice of open innovation least adopted by Portuguese SMEs, which confirmed the results of the study by Teixeira and Lopes [89], in which it was indicated that most organizations in Portugal were unaware of the economic potential of making internally created technologies available to third parties. The integration of knowledge from suppliers and clients was the most important factor explored by Portuguese SMEs in the outside-in innovation. The exchange of explicit knowledge through dialogue with customers/suppliers was easier, which enabled the sharing of knowledge among them [90]. However, as recognized by Centobelli et al. [91], 
knowledge management of these practices in SMEs is still residual, and often boils down to isolated practices of records and knowledge-sharing. This is an inhibiting factor for the growth of SMEs since, as stated in Fernandes et al. [92], cooperation with customers offers potential for Portuguese companies to innovate their core business activities. The goal would be that this approach is at the core of the organizational strategy, permeating all its processes, generating value for the business, and contributing to the sustainability of organizations and the development of society.

Licensing was the most common inside-out practice adopted by Portuguese SMEs. According to Moreira et al. [93], licensing is frequently practiced by the owners of intellectual capital that do not possess all the important complementary assets for exploitation. This is the case for many SMEs, which do not have all the internal conditions to produce and commercialize their technologies and, therefore, need to license. The application of ANOVA inversely demonstrated this situation, since the larger Portuguese SMEs were more relevant to the implementation of the inside-out approach. Hagedoorn et al. [94] also pointed out that licenses can be combined with knowledge- or technology-transfer agreements, in which the licensor hires the licensee to teach them how to use the technology. This is a practice that may be of interest in highly specialized niche markets where deeper knowledge sharing is required. The creation of spinoffs is a practice still little recognized, although the results of the study conducted by Fernandes and Castela [95] highlighted the role of incubators and science parks in promoting open innovation among smaller organizations. The adoption of coupled open innovation is mainly done through joint ventures and network consortiums. Joint ventures can be built for various purposes, such as logistic, commercial, industrial, and technological, among others. Nippa and Reuer [96] revealed that this approach was adopted to accelerate business expansion, because by joining their resources, companies had access to scarce skills and could inclusively penetrate new markets. This can be important in the context of SMEs that intend to internationalize their activities, especially in the scenario of increasing digitalization of the economy due to COVID-19 [97]. Furthermore, a strategic objective of the Portuguese government is to expand the export base of national companies, and the digitalization of this business fabric is a fundamental factor in leveraging this process [98]. The network consortia are also relevant, and arise mainly in the context of European projects that have allowed Portuguese SMEs to access foreign knowledge. These projects allow the emergence of open-innovation initiatives involving SMEs from other geographical areas. Another form of less-formal collaboration, but which became popular, especially in the context of the pandemic, is crowdsourcing. This is a model of production and process structuring that uses collective wisdom and learning to solve problems or develop a solution [99]. It is also a way for a wide diversity of players to participate in the innovation process, and an incentive to generate ideas in a short period of time [100].

The development of innovative capacity has been recognized as the main factor for the adoption of open innovation among Portuguese SMEs. While many innovations can arise as a result of organized research and development programs, these innovations can often occur not so much as a result of research and development activity, but as a result of collaborative innovation processes involving external players [101]. Innovation can take a wide variety of forms, such as a result of a creative solution by a collaborator, a new way to serve the customer, an alternative of a certain step in the production process, or the modification of an input to the new product. For smaller SMEs, especially the group of micro-companies (i.e., less than 10 employees), this was a key factor, since this category of companies was strongly affected by structural and financial limitations that restricted their ability to innovate [102].

Portuguese SMEs recognize that a lack of resources and the difficulty in integrating the knowledge generated from open-innovation practices in their organizations are two relevant challenges in the implementation of open innovation. The lack of resources associated with SMEs is widely recognized in the literature [103,104]. As expected, it is mainly micro-firms that highlight this inhibiting factor. However, the greatest difficulties 
in knowledge integration are especially recognized in larger SMEs (i.e., medium-sized companies). The challenge of knowledge integration was explored by Celadon [105], in which it was indicated that open innovation required organizations to employ individuals with the skills to integrate internal and external knowledge. Smaller organizations, such as micro-companies, typically have more agile and flexible structures, which enables them to integrate external knowledge and deal more easily with tacit knowledge issues that, according to Terhorst et al. [106], are essential for supporting innovative practices. This tacit knowledge is embedded in people's experience, and complements problem-solving skills in managing innovation.

\section{Conclusions}

Open innovation can be implemented according to multiple perspectives such as the outside-in, which consists of the absorption of external knowledge and technology to complement the internal R\&D of organizations; the inside-out, which involves the commercialization and supply of unused or underused internal ideas to third parties; and the coupled approach, in which both models are combined and complemented. In Portuguese SMEs, the practices related to outside-in tended to be more valued, essentially due to the greater ease of adoption and less need for restructuring internal innovation processes. However, larger SMEs (i.e., medium-sized companies) were more receptive to implementing inside-out practices than SMEs with less than 50 employees (i.e., small-sized and micro-companies).

The most implemented outside-in practices in Portuguese SMEs were the integration of knowledge from suppliers and clients. However, these practices were still often isolated, and without the proper sharing and management of knowledge, did not contribute decisively to the sustainability of these organizations. The licensing model was the most adopted practice in the inside-out paradigm, and mostly was exploited by medium-sized organizations. These practices also offer the potential of being combined with knowledgeor technology-transfer agreements. In the coupled approach, we highlighted the relevance of joint ventures and network consortiums, which are especially relevant in the context of internationalization of the activities of Portuguese SMEs.

The development of innovative capacity was highlighted as the main benefit of processes to implement open innovation. This was a benefit highlighted by Portuguese SMEs, but it was even more decisive for micro-companies, since this group of companies had strong structural and financial constraints that limited their ability to innovate. Among the challenges, the lack of resources and the difficulty in integrating the knowledge generated through open-innovation processes were highlighted as the main inhibitors. The lessflexible organizational structures of medium-sized innovations posed greater challenges to the integration of this knowledge.

This study offers both theoretical and practical contributions. In the conceptual dimension, this study is relevant because it explored the outside-in, inside-out, and coupled paradigms among Portuguese SMEs. Through this approach, it was possible to explore the main practices followed in each model and to identify inhibiting factors that limited their adoption. In the practical dimension, the findings are relevant for the establishment of public-support policies, nationally and regionally, to support the establishment and development of innovation networks that encourage greater empowerment of these organizations for innovation. The results indicated the need for Portuguese SMEs to foster the participation of customers in their open-innovation processes to achieve a better balance between the participation of suppliers and customers. In the establishment of public policies, the collaboration with universities and research centers should be encouraged, since the transfer of technology to Portuguese SMEs is still marginal. We also highlighted the need for public policies that foster the creation of spinoffs involving both internal and external technology and incentives for the creation of strategic alliances. Some limitations arose in this study that are relevant to address. The first limitation was that this study did not explore in detail the very heterogeneous characteristics of Portuguese SMEs. In this 
sense, and as future work, we suggest the adoption of a methodology based on mixed methods that would allow exploring this phenomenon through a qualitative study. Another limitation was that the activity sector of SMEs was not explored in depth. Only the three most representative activity sectors of the sample were considered. As future work, and in order to obtain a larger sample size, it would be desirable to consider all sectors of activity included in the EACC. Finally, another limitation was the lack of exploration at the regional level of the asymmetries between Portuguese SMEs. In this sense, and as future work, we suggest that an analysis of open-innovation practices should consider regional asymmetries, such as proximity to major urban centers and distance from major technological centers.

Funding: This research received no external funding.

Institutional Review Board Statement: Not applicable.

Informed Consent Statement: Not applicable.

Data Availability Statement: The research is based on primary data collected through questionnaire. The survey data can be retrieved from drive.google.com/file/d/1w4BuvRRhTh_G3JWNIgaCssEnmBSYycE, accessed on 23 April 2021.

Conflicts of Interest: The author declares no conflict of interest.

\section{Appendix A}

Table A1. Full structure of the questionnaire.

\section{Questions}

A1 What is the economic activity classification code of your business?

A2 How many years has your company been in business?

A3 How many employees does the company have?

A4 What is the relevance of outside-in open innovation for your company?

A4.1 Are the suppliers involved in the outside-in process?

A4.2 Are the customers involved in the outside-in process?

A4.3 Are the competitors involved in the outside-in process?

A4.4 Are the universities involved in the outside-in process?

A4.5 Are the R\&D centers involved in the outside-in process?

A5 What is the relevance of inside-out open innovation for your company?

A5.1 Does your company adopt the licensing model in the inside-out process?

A5.2 Does your company adopt the creation of a spinoff model in the inside-out process?

A5.3 Does your company adopt the outsourcing of innovation model in the inside-out process?

A6 What is the relevance of coupled open innovation for your company?

A6.1 Does your company use joint ventures in the coupled open innovation?

A6.2 Does your company use strategic alliances in the coupled open innovation?

A6.3 Does your company use network consortiums in the coupled open innovation?

B1. What are the benefits of open innovation for your company considering the following dimensions?

B1.1 Development of innovative capacity

B1.2 Cost reduction

B1.3 Diversification

B1.4 Reduced time to market

B1.5 Risk-sharing

B1.6 Increased acceptance of innovation

B2. What are the challenges of open innovation for your company considering the following dimensions?

B2.1 Lack of resources

B2.2 Lack of competencies

B2.3 Difficulties in integrating knowledge

B2.4 Loss of control

B2.5 Cultural challenges 


\section{References}

1. Pece, A.M.; Simona, O.E.; Salisteanu, F. Innovation and Economic Growth: An Empirical Analysis for CEE Countries. Procedia Econ. Financ. 2015, 26, 461-467. [CrossRef]

2. Maradana, R.P.; Pradhan, R.P.; Dash, S.; Gaurav, K.; Jayakumar, M.; Chatterjee, D. Does innovation promote economic growth? Evidence from European countries. J. Innov. Entrep. 2017, 6, 1-23. [CrossRef]

3. Lopes, J.M.; Gomes, S.; Oliveira, J.; Oliveira, M. The Role of Open Innovation, and the Performance of European Union Regions. J. Open Innov. Technol. Mark. Complex. 2021, 7, 120.

4. Maier, D.; Maier, A.; Aschilean, I.; Anastasiu, L.; Gavris, O. The Relationship between Innovation and Sustainability: A Bibliometric Review of the Literature. Sustainability 2020, 12, 4083. [CrossRef]

5. Drucker, P.F. Innovation and Entrepreneurship; Harper Business: New York, NY, USA, 2006.

6. Felin, T.; Zenger, T.R. Closed or open innovation? Problem solving and the governance choice. Res. Policy 2014, 43, 914-925. [CrossRef]

7. Yun, J.J.; Jeon, J.; Park, K.; Zhao, X. Benefits and Costs of Closed Innovation Strategy: Analysis of Samsung's Galaxy Note 7 Explosion and Withdrawal Scandal. J. Open Innov. Technol. Mark. Complex. 2018, 4, 20. [CrossRef]

8. Chabowski, B.R.; Mena, J.A. A Review of Global Competitiveness Research: Past Advances and Future Directions. J. Int. Mark. 2017, 25, 1-24. [CrossRef]

9. Momaya, K.S. The Past and the Future of Competitiveness Research: A Review in an Emerging Context of Innovation and EMNEs. Int. J. Glob. Bus. Compet. 2019, 14, 1-10. [CrossRef]

10. Bigliardi, B.; Ferraro, G.; Filippelli, S.; Galati, F. The past, present and future of open innovation. Eur. J. Innov. Manag. 2021. In Press. [CrossRef]

11. Chesbrough, H.W. Open Innovation: The New Imperative for Creating and Profiting from Technology; Harvard Business Press: Brighton, MA, USA, 2003.

12. Wikhamn, B.R.; Wikhamn, W. Structuring of the Open Innovation Field. J. Technol. Manag. Innov. 2013, 8, $173-185$.

13. Grimaldi, M.; Quinto, I.; Rippa, P. Enabling Open Innovation in Small and Medium Enterprises: A Dynamic Capabilities Approach. Knowl. Process Manag. 2013, 20, 199-210. [CrossRef]

14. Radziwon, A.; Bogers, M. Open innovation in SMEs: Exploring inter-organizational relationships in an ecosystem. Technol. Forecast. Soc. Chang. 2019, 146, 573-587. [CrossRef]

15. Eurostat. Small and Medium-Sized Enterprises: An Overview. Available online: https://ec.europa.eu/eurostat/web/productseurostat-news/- /EDN-20191125-1?inheritRedirect=true\&redirect=\%2Feurostat\%2F (accessed on 23 April 2021).

16. Marques, J. Closed versus Open Innovation: Evolution or Combination? Int. J. Bus. Manag. 2014, 9, 196-203. [CrossRef]

17. Vanhaverbeke, W.; Van de Vrande, V.; Chesbrough, H. Understanding the Advantages of Open Innovation Practices in Corporate Venturing in Terms of Real Options. Creat. Innov. Manag. 2008, 17, 251-258. [CrossRef]

18. Lassen, A.H.; Laugen, B.T. Open innovation: On the influence of internal and external collaboration on degree of newness. Bus. Process Manag. J. 2017, 23, 1129-1143. [CrossRef]

19. Bican, P.M.; Guderian, C.C.; Ringbeck, A. Managing knowledge in open innovation processes: An intellectual property perspective. J. Knowl. Manag. 2017, 21, 1384-1405. [CrossRef]

20. Grimaldi, M.; Greco, M.; Cricelli, L. A framework of intellectual property protection strategies and open innovation. J. Bus. Res. 2021, 123, 156-164. [CrossRef]

21. Chatzoglou, P.; Chatzoudes, D. The role of innovation in building competitive advantages: An empirical investigation. Eur. J. Innov. Manag. 2018, 21, 44-69. [CrossRef]

22. Hana, U. Competitive Advantage Achievement through Innovation and Knowledge. J. Compet. 2013, 5, 82-96.

23. Aghion, P.; Jaravel, X. Knowledge Spillovers, Innovation and Growth. Econ. J. 2015, 125, 533-573. [CrossRef]

24. Ramadani, V.; Abazi-Alili, H.; Dana, L.P.; Rexhepi, G.; Ibraimi, S. The impact of knowledge spillovers and innovation on firm-performance: Findings from the Balkans countries. Int. Entrep. Manag. J. 2017, 13, 299-325. [CrossRef]

25. Audretsch, D.B.; Belitski, M.; Caiazza, R. Start-ups, Innovation and Knowledge Spillovers. J. Technol. Transf. 2021. In Press. [CrossRef]

26. Leitão, J.; Pereira, D.; Brito, S. Inbound and Outbound Practices of Open Innovation and Eco-Innovation: Contrasting Bioeconomy and Non-Bioeconomy Firms. J. Open Innov. Technol. Mark. Complex. 2020, 6, 145. [CrossRef]

27. Enkel, E.; Gassmann, O.; Chesbrough, H. Open R\&D and open innovation: Exploring the phenomenon. RD Manag. 2009, 39, 311-316.

28. Inauen, M.; Schenker-Wicki, A. The impact of outside-in open innovation on innovation performance. Eur. J. Innov. Manag. 2011, 14, 496-520. [CrossRef]

29. Becker, B.A.; Eube, C. Open innovation concept: Integrating universities and business in digital age. J. Open Innov. Technol. Mark. Complex. 2018, 4, 12. [CrossRef]

30. Lau, A.K.; Lee, L.W.; Lai, L.H.; Lee, P.K. Adopting an Open Innovation Program with Supply Chain Management in China: A Case Study. Eng. Manag. J. 2018, 30, 24-41. [CrossRef]

31. Vélez-Rolón, A.M.; Méndez-Pinzón, M.; Acevedo, O.L. Open Innovation Community for University-Industry Knowledge Transfer: A Colombian Case. J. Open Innov. Technol. Mark. Complex. 2020, 6, 181. 
32. Aziz, F.; Mahadi, N.; Zakaria, W.N.; Mahadi, N. The Impact of Open Innovation and Supply Chain Management towards Firm Performance. Int. J. Acad. Res. Bus. Soc. Sci. 2017, 7, 338-344. [CrossRef]

33. Shcherbakov, V.; Silkina, G. Supply Chain Management Open Innovation: Virtual Integration in the Network Logistics System. J. Open Innov. Technol. Mark. Complex. 2021, 7, 54.

34. Sjödin, D.; Parida, V.; Kohtamäki, M.; Wincent, J. An agile co-creation process for digital servitization: A micro-service innovation approach. J. Bus. Res. 2020, 112, 478-491. [CrossRef]

35. Liu, Q.; Zhao, X.; Sun, B. Value co-creation mechanisms of enterprises and users under crowdsource-based open innovation. Int. J. Crowd Sci. 2018, 2, 2-17. [CrossRef]

36. Yang, H.; Steensma, H.K. When do firms rely on their knowledge spillover recipients for guidance in exploring unfamiliar knowledge? Res. Policy 2014, 43, 1496-1507. [CrossRef]

37. Imbriani, C.; Pittiglio, R.; Reganati, F.; Sica, E. How much do Technological Gap, Firm Size, and Regional Characteristics Matter for the Absorptive Capacity of Italian Enterprises? Int. Adv. Econ. Res. 2014, 20, 57-72. [CrossRef]

38. Laperche, B.; Liu, Z. SMEs and knowledge-capital formation in innovation networks: A review of literature. J. Innov. Entrep. 2013, 2, 21. [CrossRef]

39. Vicente-Saez, R.; Gustafsson, R.; Van den Brande, L. The dawn of an open exploration era: Emergent principles and practices of open science and innovation of university research teams in a digital world. Technol. Forecast. Soc. Chang. 2020, $156,120037$. [CrossRef]

40. West, J.; Bogers, M. Leveraging External Sources of Innovation: A Review of Research on Open Innovation. J. Prod. Innov. Manag. 2014, 31, 814-831. [CrossRef]

41. Sivam, A.; Dieguez, T.; Ferreira, L.P.; Silva, F.J. Key settings for successful Open Innovation Arena. J. Comput. Des. Eng. 2019, 6, 507-515. [CrossRef]

42. Paiva, T.; Ribeiro, M.; Coutinho, P. R\&D Collaboration, Competitiveness Development, and Open Innovation in R\&D. J. Open Innov. Technol. Mark. Complex 2020, 6, 116.

43. Jonsson, L.; Baraldi, E.; Larsson, L.E.; Forsberg, P.; Severinsson, K. Targeting Academic Engagement in Open Innovation: Tools, Effects and Challenges for University Management. J. Knowl. Econ. 2015, 6, 522-550. [CrossRef]

44. Davies, G.H.; Flanagan, J.; Bolton, D.; Roderick, S.; Joyce, N. University knowledge spillover from an open innovation technology transfer context. Knowl. Manag. Res. Pract. 2021, 19, 84-93. [CrossRef]

45. Comai, A. A new approach for detecting open innovation in patents: The designation of inventor. J. Technol. Transf. 2020, 45, 1797-1822. [CrossRef]

46. De Groote, J.K.; Backmann, J. Initiating open innovation collaborations between incumbents and startups: How can David and Goliath get along? Int. J. Innov. Manag. 2020, 24, 2050011. [CrossRef]

47. Arias-Pérez, J.; Lozada, N.; Henao-García, E. When it comes to the impact of absorptive capacity on co-innovation, how really harmful is knowledge leakage? J. Knowl. Manag. 2020, 24, 1841-1857. [CrossRef]

48. Kim, B.; Kim, E.; Foss, N.J. Balancing absorptive capacity and inbound open innovation for sustained innovative performance: An attention-based view. Eur. Manag. J. 2016, 34, 80-90. [CrossRef]

49. Spithoven, A.; Vanhaverbeke, W.; Roijakkers, N. Open innovation practices in SMEs and large enterprises. Small Bus. Econ. 2013, 41, 537-562. [CrossRef]

50. Bogers, M.; Chesbrough, H.; Heaton, S.; Teece, D.J. Strategic Management of Open Innovation: A Dynamic Capabilities Perspective. Calif. Manag. Rev. 2019, 62, 77-94. [CrossRef]

51. Aytac, B.; Wu, S.D. Characterization of demand for short life-cycle technology products. Ann. Oper. Res. 2013, $203,255-277$. [CrossRef]

52. Abulrub, A.H.; Lee, J. Open innovation management: Challenges and prospects. Procedia Soc. Behav. Sci. 2012, 41, 130-138. [CrossRef]

53. Lee, K.; Yoo, J. How does open innovation lead competitive advantage? A dynamic capability view perspective. PLoS ONE 2019, 14, e0223405. [CrossRef]

54. Laursen, K.; Salter, A.J. The paradox of openness: Appropriability, external search and collaboration. Res. Policy Open Innov. New Insights Evid. 2014, 43, 867-878. [CrossRef]

55. Bénézech, D. The Open Innovation model: Some issues regarding its internal consistency. J. Innov. Econ. Manag. 2012, 2, 145-165. [CrossRef]

56. Silva, M.A. Open innovation and IPRs: Mutually incompatible or complementary institutions? J. Innov. Knowl. 2019, 4, 248-252. [CrossRef]

57. Dahlander, L.; Gann, D.M. How Open is Innovation? Res. Policy 2010, 39, 699-709. [CrossRef]

58. Mazzola, E.; Bruccoleri, M.; Perrone, G. The effect of inbound, outbound and coupled innovation on performance. Int. J. Innov. Manag. 2012, 16, e1240008. [CrossRef]

59. Chesbrough, H.; Vanhaverbeke, W.; West, J. New Frontiers in Open Innovation; Oxford University Press: Oxford, UK, 2014.

60. Grimaldi, M.; Corvello, V.; De Mauro, A.; Scarmozzino, E. A systematic literature review on intangible assets and open innovation. Knowl. Manag. Res. Pract. 2017, 15, 90-100. [CrossRef]

61. Yun, J.; Cho, B.J. An exploratory study of the economic effect of open innovation. J. Sci. Technol. Policy Manag. 2014, 5, 24-40. 
62. Gallaud, D.; Nayaradou, M. Open innovation and co-operation: Which choice of means of protection for innovation? J. Innov. Econ. Manag. 2012, 2, 167-190. [CrossRef]

63. Verdú, F.M.; Tierno, N.R. Special issue: Clustering and innovation: Firm-level strategizing and policy. Entrep. Reg. Dev. 2019, 31, 1-6. [CrossRef]

64. Leenders, R.T.; Dolfsma, W.A. Social Networks for Innovation and New Product Development. J. Prod. Innov. Manag. 2016, 33, 123-131. [CrossRef]

65. Montoro-Sánchez, A.; Ortiz-de-Urbina-Criado, M.; Mora-Valentín, E.M. Effects of knowledge spillovers on innovation and collaboration in science and technology parks. J. Knowl. Manag. 2011, 15, 948-970. [CrossRef]

66. Hossain, M. A review of literature on open innovation in small and medium-sized enterprises. J. Glob. Entrep. Res. 2015, 5, 6. [CrossRef]

67. Pierre, A.; Fernandez, A.S. Going Deeper into SMEs' Innovation Capacity: An Empirical Exploration of Innovation Capacity Factors. J. Innov. Econ. Manag. 2018, 1, 139-181. [CrossRef]

68. Hvolkova, L.; Klement, L.; Klementova, V.; Kovalova, M. Barriers Hindering Innovations in Small and Medium-Sized Enterprises J. Compet. 2019, 11, 51-67. [CrossRef]

69. Hossain, M.; Kauranen, I. Open innovation in SMEs: A systematic literature review. J. Strategy Manag. 2016, 9, 58-73. [CrossRef]

70. Hutter, K.; Hautz, J.; Repke, K.; Matzler, K. Open innovation in small and micro enterprises. Probl. Perspect. Manag. 2013, 11, $12-22$.

71. Henttonen, K.; Lehtimäki, H. Open innovation in SMEs: Collaboration modes and strategies for commercialization in technologyintensive companies in forestry industry. Eur. J. Innov. Manag. 2017, 20, 329-347. [CrossRef]

72. Ye, J.; Kankanhalli, A. Exploring innovation through open networks: A review and initial research questions. IIMB Manag. Rev. 2013, 25, 69-82. [CrossRef]

73. Walecka-Jankowska, K.; Zimmer, J. Open innovation in the context of organisational strategy. Eng. Manag. Prod. Serv. 2019, 11, 86-95. [CrossRef]

74. Paulo, A.F.; Oliveira, S.V.; Porto, G.S. Mapping impacts of open innovation practices in a firm competitiveness. J. Technol. Manag. Innov. 2017, 12, 108-117. [CrossRef]

75. Oumlil, R.; Juiz, C. An Up-to-date Survey in Barriers to Open Innovation. J. Technol. Manag. Innov. 2016, 11, 137-152. [CrossRef]

76. McPhillips, M. Trouble in Paradise? Barriers to Open Innovation in Regional Clusters in the Era of the 4th Industrial Revolution. J. Open Innov. Technol. Mark. Complex. 2020, 6, 84. [CrossRef]

77. Faria, P.; Noseleit, F.; Los, B. The influence of internal barriers on open innovation. Ind. Innov. 2020, 27, 205-209. [CrossRef]

78. Rauter, R.; Globocnik, D.; Perl-Vorbach, E.; Baumgartner, R.J. Open innovation and its effects on economic and sustainability innovation performance. J. Innov. Knowl. 2019, 4, 226-233. [CrossRef]

79. Aquilani, B.; Abbate, T.; Codini, A. Overcoming cultural barriers in open innovation processes through intermediaries: A theoretical framework. Knowl. Manag. Res. Pract. 2017, 5, 447-459. [CrossRef]

80. Bergin, T. An Introduction to Data Analysis: Quantitative, Qualitative and Mixed Methods; SAGE Publications: Thousand Oaks, CA, USA, 2018.

81. European Commission. SME Definition. Available online: https://ec.europa.eu/growth/smes/sme-definition_en (accessed on 28 April 2021).

82. Hoekstra, R.; Vugteveen, J.; Warrens, M.J.; Kruyen, P.M. An empirical analysis of alleged misunderstandings of coefficient alpha. Int. J. Soc. Res. Methodol. 2019, 22, 351-364. [CrossRef]

83. Taber, K.S. The Use of Cronbach's Alpha When Developing and Reporting Research Instruments in Science Education. Res. Sci. Educ. 2018, 48, 1273-1296. [CrossRef]

84. Vik, P.W. Regression, ANOVA, and the General Linear Model: A Statistics Primer; SAGE Publication: Hoboken, NJ, USA, 2013.

85. Arvanitis, S.; Fuchs, B.; Woerter, M. Opening up the Innovation Process: Outside-in Involvement of Innovative Users and Established Firms' Innovation Performance. Int. J. Innov. Manag. 2019, 19, 1550029.

86. Gómez, M.S.; Chincha, J.A.; Aedo-Cobo, J.E. Mechanisms to manage intellectual property in collaborative innovation projects. Rev. Int. Organ. 2016, 16, 83-98.

87. COTEC Portugal. Assessing Digital Maturity in Order to Evolve. Available online: https://cotecportugal.pt/en/2020/08/31 /assessing-digital-maturity-in-order-to-evolve/ (accessed on 26 June 2021).

88. Flor, M.L.; Díaz, J.L.; Ortiz, M.L. Innovation policy instruments through the lens of open innovation. An analysis in the Spanish context. J. Evol. Stud. Bus. 2020, 5, 52-80. [CrossRef]

89. Teixeira, A.C.; Lopes, M. Open Innovation in Portugal. Acta Oeconomica 2012, 62, 435-458. [CrossRef]

90. Cheng, C.C.; Shiu, E.C. Establishing a typology of open innovation strategies and their differential impacts on innovation success in an Asia-Pacific developed economy. Asia Pac. J. Manag. 2021, 38, 65-89. [CrossRef]

91. Centobelli, P.; Cerchione, R.; Esposito, E. Efficiency and effectiveness of knowledge management systems in SMEs. Prod. Plan. Control 2019, 30, 779-791. [CrossRef]

92. Fernandes, S.; Cesário, M.; Barata, J.M. Ways to open innovation: Main agents and sources in the Portuguese case. Technol. Soc. 2017, 51, 153-162. [CrossRef]

93. Moreira, S.; Klueter, T.M.; Tasselli, S. Competition, Technology Licensing-in, and Innovation. Organ. Sci. 2020, 31, 797-1051. [CrossRef] 
94. Hagedoorn, J.; Lorenz-Orlean, S.; Kranenburg, H. Inter-firm technology transfer: Partnership-embedded licensing or standard licensing agreements? Ind. Corp. Chang. 2009, 18, 529-550. [CrossRef]

95. Fernandes, S.; Castela, G. Start-ups' accelerators support open innovation in Portugal. Int. J. Innov. Learn. 2019, 26, 82-93. [CrossRef]

96. Nippa, M.; Reuer, J. On the future of international joint venture research. J. Int. Bus. Stud. 2019, 50, 555-597. [CrossRef]

97. Almeida, F.; Santos, J.D.; Monteiro, J.A. The Challenges and Opportunities in the Digitalization of Companies in a Post COVID-19 World. IEEE Eng. Manag. Rev. 2020, 48, 97-103. [CrossRef]

98. AICEP. Incentivos Portugal 2020. Available online: https://www.portugalexporta.pt/produtos-e-servicos/incentivosexportacao-portugal-2020 (accessed on 12 May 2021).

99. Schenk, E.; Guittard, C. Towards a characterization of crowdsourcing practices. J. Innov. Econ. Manag. 2011, 7, 93-107. [CrossRef]

100. Almeida, F.; Kennedy, A.J.; Lin, B.; Nowak, I.V. Measuring innovation through a crowd source initiative. Int. J. Innov. Sci. 2019, 11, 471-488. [CrossRef]

101. Gay, B. Open innovation, networking, and business model dynamics: The two sides. J. Innov. Entrep. 2014, 3, 2 . [CrossRef]

102. Butryumova, N.; Karpycheva, S.; Grisheva, K.; Kasyanova, E. Obstacles to Small Innovative Companies' Development: Case Study of Nizhny Novgorod Region. J. Technol. Manag. Innov. 2015, 10, 74-84. [CrossRef]

103. Sadat, S.H.; Nasrat, S. The Practice of Open Innovation by SMEs in the Food Industry. J. Innov. Manag. 2020, 8, 26-46. [CrossRef]

104. Wynarczyk, P.; Piperopoulos, P.; McAdam, M. Open innovation in small and medium-sized enterprises: An overview. Int. Small Bus. J. Res. Entrep. 2013, 31, 240-255. [CrossRef]

105. Celadon, K.L. Knowledge Integration and Open Innovation in the Brazilian Cosmetics Industry. J. Technol. Manag. Innov. 2014, 9 , 34-50. [CrossRef]

106. Terhorst, A.; Lusher, D.; Bolton, D.; Elsum, I.; Wang, P. Tacit Knowledge Sharing in Open Innovation Projects. Proj. Manag. J. 2018, 49, 5-19. [CrossRef] 